\title{
The relationship between endothelial progenitor cells and pulmonary arterial hypertension in children with congenital heart disease
}

\author{
Hong-Xiao Sun ${ }^{1,2+}$, Guo-Ju Li ${ }^{2 \dagger}$, Zhan-Hui Du², Zhen Bing ${ }^{2}$, Zhi-Xian $\mathrm{Ji}^{2}$, Gang Luo ${ }^{2}$ and Si-Lin Pan ${ }^{2 *}$
}

\begin{abstract}
Background: Pulmonary arterial hypertension (PAH) caused by congenital heart disease (CHD) is very common in clinics. Some studies have shown that PAH is related to the number of endothelial progenitor cells (EPCs), but there is no report on the relationship between PAH and the number of EPCs in children with CHD.

Methods: In this study, a total of 173 cases with CHD (from 0 to 6 years old) were collected. According to the mean pulmonary arterial pressure (mPAP) measured by right heart catheterization, these cases were divided into PAH groups (including high PAH group, mPAP> $25 \mathrm{mmHg}, n=32$, and the middle PAH group, $20 \mathrm{mmHg} \leq$ $\mathrm{mPAP} \leq 25 \mathrm{mmHg}, n=30$ ) and non-PAH group (mPAP $<20 \mathrm{mmHg}, n=111)$. Peripheral blood was taken for flow cytometry, and the number of EPCS (CD133+/KDR+ cells) was counted. The number of EPCs $/ \mu \mathrm{L}$ of peripheral blood was calculated using the following formula: EPCs $/ \mu \mathrm{L}=\mathrm{WBC} / \mathrm{L} \times$ lymphocytes $\% \times \mathrm{EPCS} \% \times 10^{-6}$.

Results: The median EPCs of the non-PAH group, middle PAH group and high PAH group is $1.86 / \mu \mathrm{L}, 1.30 / \mu \mathrm{L}$ and $0.98 / \mu \mathrm{L}$, respectively. The mPAP decreases steadily as the level of EPCs increases $(P<0.05)$. After adjustment of gender, age and BMl, the number of EPCS was significantly associated with a decreased risk of high PAH $(O R=0.37$, 95\% Cl: 0.16-0.87, $P<0.05)$. However, EPCs was not significantly associated with middle PAH $(P>0.05)$.

Conclusion: The findings revealed that the EPCS and high PAH in patients with CHD correlate significantly and EPCs may become an effective treatment for PAH in patients with CHD. EPCs may be a protective factor of high PAH for children with CHD.
\end{abstract}

Keywords: Child, Congenital heart disease, endothelial progenitor cells, pulmonary arterial hypertension

\section{What is known of this subject}

- Pulmonary arterial hypertension (PAH) caused by congenital heart disease (CHD) is very common in the clinic, about $4-10 \%$ of CHD patients develop $\mathrm{PAH}$, the prevalence of CHD-related PAH is about 25 people per million in the general population; patients with $\mathrm{CHD}$ and $\mathrm{PAH}$ have at least a doubled mortality risk compared with patients with $\mathrm{CHD}$ without PAH.

- To our knowledge, there were few studies of the relationship between endothelial progenitor cells (EPCs) and CHD-related PAH. The purpose of this study was to investigate the relationship between the number of EPCs and CHD-related PAH in children.

\section{What is new from this study}

\footnotetext{
* Correspondence: silinpan@126.com

${ }^{\dagger}$ Hong-Xiao Sun and Guo-Ju Li contributed equally to this work.

${ }^{2}$ Heart Center, Qingdao Women and Children's Hospital, Qingdao 266034

Shandong, China

Full list of author information is available at the end of the article
}

- This study was the first to study the relationship between EPCs and PAH in children with CHD.

- We found that mPAP declined steadily with the increase of the level of EPCs. 
- The EPCs and high PAH in CHD patients correlate significantly.

\section{Background}

Pulmonary arterial hypertension (PAH) is a common clinical disease which can exist independently. It is mainly the manifestation of many diseases when they progress to a certain stage, namely secundum PAH [1]. In clinic, left-to-right shunt congenital heart disease (CHD) will increase the right cardiac blood flow, thus damaging the pulmonary artery and causing PAH [2]. The statistics show that about $4-10 \%$ of CHD patients develop PAH [3-7]. The global prevalence of PAH is about 1 , and $80 \%$ of the patients live in developing countries. The prevalence of CHD-related PAH is about 25 people per million in the general population. The deaths of patients with both $\mathrm{PAH}$ and $\mathrm{CHD}$ are at least twice as many as those without PAH [1]. PAH is very common in children, mainly due to $\operatorname{CHD}[2,7,8]$.

In 1997, Asahara et al. [9] first isolated a kind of cells from human peripheral blood that could be cultured into endothelial cells in vitro. Stimulated by various factors, these cells entered the peripheral blood from the bone marrow to participate in the formation of new blood vessels and repair the damaged endothelial cells. These cells were called endothelial progenitor cells (EPCs). EPCs are bone-marrow-derived cells with the ability to differentiate into endothelial cells, repair and regenerate damaged pulmonary blood vessels. Previous experimental studies have found that EPCs can be applied to the treatment of lung injury [10-12]. There have been many studies demonstrating that the number of EPCs is related to PAH, but the results are inconsistent [13-16]. To our knowledge, there are no studies on the relationship between EPCs and PAH in children with $\mathrm{CHD}$. The purpose of this study was to investigate the relationship between the number of EPCs and PAH in children with CHD and to explore the possibility of applying EPCs to treatment of $\mathrm{PAH}$ in children with CHD.

\section{Methods Subjects}

From August 2011 to September 2017, 173 patients with CHD aging from 0 to 6 years old and hospitalized in Qingdao Women and Children's Hospital were selected as the study subjects, including 98 having patent ductus arteriosus (PDA), 58 with atrial aeptal defect (ASD) and 17 with ventricular septal defect (VSD). All patients were preoperative. Patients with lung diseases, connective tissue diseases, HIV infection, portal hypertension, schistosomiasis and other diseases that may cause the increase of PAH were excluded in this study.

\section{Measurements}

According to the "2010 ESC Guidelines for the Management of Grown-up Congenital Heart Disease", the diagnosis of CHD was based on echocardiography [17]. Mean pulmonary arterial pressure (mPAP) was measured by right heart catheterization. According to "the 6th World Symposium on Pulmonary Hypertension" [18], patients were divided into $\mathrm{PAH}$ groups, including high $\mathrm{PAH}$ group (mPAP $>25 \mathrm{mmHg}, 32$ patients) and the middle $\mathrm{PAH}$ group $(20 \mathrm{mmHg} \leq \mathrm{mPAP} \leq 25 \mathrm{mmHg}, 30$ patients); the non-PAH group (mPAP $<20 \mathrm{mmHg}, n=111)$.

Peripheral blood samples were collected for flow cytometry using a FACS Calibur cytometer (Becton Dickinson, USA). We added FcR-blocking reagent (eBiosciences, USA) into the samples and incubated them, then added selective antibodies (Mouse anti-human CD133-PE, Miltenyi Biotec $\mathrm{GmbH}$, Germany; Mouse anti-human KDRAPC, R\&D Systems, USA). Labeled immunoglobulins (Mouse anti-human IgG1-PE, Shenzhen Jingmei, China; Mouse anti-human IgG1-APC, Shenzhen Jingmei, China) were applied for each sample as a negative control. After incubation, the lysing solution (MasterTech, USA) was used to eliminate erythrocytes cells. Horizontal centrifuge (Shanghai anting, China), centrifuged at $250 \mathrm{~g}$ at $4^{\circ} \mathrm{C}$ with brake for $5 \mathrm{~min}$ to remove the supernatant. Finally, the number of $\mathrm{CD} 133+/ \mathrm{KDR}+$ cells was counted. The number of monocytes in human peripheral blood is about 0.30 $0.80 \times 10^{9} / \mathrm{L}$; the proportion of EPCs is about $0.01 \%$; the number of EPCs is estimated to be $0.30-1.00 / \mu \mathrm{L}[19,20]$. Thus, the number of EPCs $<1.00 / \mu \mathrm{L}$ was used as the control. The number of EPCs $/ \mu \mathrm{L}$ of peripheral blood was calculated by using the following formula: $\mathrm{EPCs} / \mu \mathrm{L}=\mathrm{WBC} /$ $\mathrm{L} \times$ lymphocytes $\% \times \mathrm{EPCs} \% \times 10^{-}$6[9]. Body mass index (BMI) was calculated as the subject's weight $(\mathrm{kg})$ divided by the height squared (meters).

\section{Statistical analysis}

The data were expressed as the mean \pm standard deviation for normally distributed continuous variables and compared by one-way analyses of variance. Median values (inter-quartile range) were used and compared by Mann-Whitney $U$ test when the parameters exhibited skewed deviations. The number and proportions in each subgroup of categorical variables were compared by the Mann-Whitney $U$ test. The multiple comparisons in each subgroup were made by Bonferroni test or Student-Newman-Keuls test. A multinomial logit analysis was performed to explore relationships between the number of EPCs and PAH severity after adjustment of age, gender, and BMI. All $P$-values less than 0.05 were considered to be statistically significant. All of the analyses were performed using SAS 9.4 (SAS Institute Inc., Cary, NC, USA). 


\section{Results}

In the present study, a total of $173 \mathrm{CHD}$ patients met all analysis criteria, including 111 (64.16\%) non-PAH patients, 30 (17.34\%) middle PAH patients and 32 (18.50\%) high PAH patients. The general characteristics of the non$\mathrm{PAH}$ group, middle $\mathrm{PAH}$ group and high $\mathrm{PAH}$ group are shown in Table 1. The median age of the non-PAH patients, middle $\mathrm{PAH}$ patients and high $\mathrm{PAH}$ patients is 2 years, 2 years, and 0 years, respectively. The median age was lower in the high PAH group than in the middle PAH and non-PAH groups (Student-Newman-Keuls test, all $P<0.05)$. BMI, WBC, and lymphocyte are similar in the three subgroups (all $P>0.05$ ). The proportion of EPCs> $1.00 / \mu \mathrm{L}$ of the non-PH group, middle $\mathrm{PH}$ group and high $\mathrm{PH}$ group is $70.27,70.00$ and 50.00 , respectively, and the proportion of EPCs $>1.00 / \mu \mathrm{L}$ is significantly reduced among the high PAH patients compared with the EPCs< $1.00 / \mu \mathrm{L}(P=0.05)$. With the non-PAH group as a reference, the associations between EPCs and mPAP levels were estimated in multinomial logistic models (Table 2). EPCs was significantly associated with a decreased risk of high PAH $(\mathrm{OR}=0.42$, 95\%CI: 0.19-0.95, $P<0.05)$. We next adjusted age and gender, and examined the associations between the number of EPCs and mPAP levels, and the results showed that the number of EPCs was significantly associated with a decreased risk of high $\mathrm{PAH}(\mathrm{OR}=$ 0.38, 95\%CI: 0.17-0.87, $P<0.05)$. After adjustment of gender, age and BMI, the EPCs was also significantly associated with a decreased risk of high PAH $(\mathrm{OR}=0.37$, 95\%CI: $0.16-0.87, P<0.05)$. However, EPCs was not significantly associated with middle PAH $(P>0.05)$.

\section{Discussion}

$\mathrm{PAH}$ is a pathophysiological syndrome caused by known or unknown factors, characterized by pulmonary vascular contraction, remodeling and in situ thrombosis. Generally, endothelial dysfunction, oxidative stress, inflammation, and angiogenesis disorders are considered as the main causes. The progressive increase of pulmonary vascular resistance restricts blood flow and causes an abnormal increase of pulmonary artery pressure, eventually leading to hemodynamic changes in pulmonary circulation, impaired right heart function, and even death [2, 21, 22]. The previous $\mathrm{PAH}$ is defined as $\mathrm{mPAP} \geq 25 \mathrm{mmHg}$ in children $>3$ months of age at sea level, mPAP $\geq 25 \mathrm{mmHg}$, PCWP < $15 \mathrm{mmHg}$, PVR index $>3 \mathrm{WU} \times \mathrm{m} 2$ [23]. According to the guideline, the normal $\mathrm{mPAP}$ value is $14 \pm 3.30 \mathrm{mmHg}$ when people are resting, and the mPAP should not exceed $20 \mathrm{mmHg}$ under normal circumstances even considering age, gender, race, and other related factors. In our study, the mPAP is $14.82 \pm 2.04 \mathrm{mmHg}$ in non-PAH groups, similar to the above study. Recent studies have found that patients with mPAP ranging $20 \mathrm{mmHg}<\mathrm{mPAP} \leq 25$ $\mathrm{mmHg}$ have a significantly increased risk of disease progression. Therefore, $20 \mathrm{mmHg}<\mathrm{mPAP} \leq 25 \mathrm{mmHg}$ can be considered as the early stage of pulmonary vascular disease $[18,24]$.

Some studies have suggested that peripheral blood EPCs may be derived from bone marrow EPCs, and blood sampling is a relatively non-invasive method compared with bone marrow puncture $[25,26]$. Therefore, studies on EPCs have shifted from bone marrow EPCs to peripheral blood EPCs in recent years. It can be seen that EPCs in peripheral blood are biomarkers of various pathophysiological states. Because flow cytometry is relatively sensitive to the identification of biomarkers, it has high universality and usability. During the past decade, this technology has developed rapidly and become the mainstream method for separation, classification, and analysis of EPCs [27-29]. EPCs are counted by flow cytometry using different markers or combinations of them. There is still a considerable controversy over the phenotype of EPCs. Currently, the common expression of CD34, CD133, and VEGFR2 is most widely used for the identification of EPCs. The human expression of VEGFR2 is also known as $\operatorname{KDR}[16,19,24]$. CD133 is

Table 1 Demographic characteristic of the study population

\begin{tabular}{|c|c|c|c|c|c|c|}
\hline \multirow[t]{2}{*}{ Variables } & \multicolumn{3}{|l|}{$\mathrm{PAH}$} & \multirow[t]{2}{*}{ Non-PAH } & \multirow[t]{2}{*}{ statistics } & \multirow[t]{2}{*}{$P$ value } \\
\hline & $20-25 \mathrm{mmHg}$ & $>25 \mathrm{mmHg}$ & Total (> 20 mmHg) & & & \\
\hline Number & 30 & 32 & 62 & 111 & & \\
\hline Female, $\%$ & $20(66.67)$ & $20(62.50)$ & $40(64.52)$ & $55(49.55)$ & 2.64 & 0.10 \\
\hline Age, mean (SD), years & $2(1-3)$ & $0(0-2) b c$ & $1(0-3)$ & $2(0-3)$ & 6.53 & 0.04 \\
\hline BMI, mean (SD), $\mathrm{kg} / \mathrm{m}^{2}$ & $16.09 \pm 2.24$ & $15.17 \pm 2.04$ & $15.62 \pm 2.18$ & $16.16 \pm 2.47$ & 2.23 & 0.11 \\
\hline $\operatorname{WBC}\left(\times 10^{9} / \mathrm{L}\right)$ & $8.50(7.30-10.16)$ & 8.80 (7.47-9.96) & $8.75(7.40-10.00)$ & $8.70(6.80-10.20)$ & 0.44 & 0.80 \\
\hline lymphocyte(×10\%/L) & $4.46(3.51-5.45)$ & $5.07(3.53-6.51)$ & $4.97(3.51-6.20)$ & 4.69 (3.37-6.19) & 0.43 & 0.81 \\
\hline EPCs> $1.00 / \mu \mathrm{L}, \%$ & $21(70.00)$ & $16(50.00)$ & 37 (59.68) & $78(70.27)$ & 3.75 & 0.05 \\
\hline mPAP, mmHg & $22.00 \pm 1.72^{\mathrm{a}}$ & $35.69 \pm 8.76^{\mathrm{bc}}$ & $29.06 \pm 9.38$ & $14.82 \pm 2.04$ & -11.80 & $<0.0001$ \\
\hline
\end{tabular}

a: denotes statistical significance between Non-PAH and PAH $(20-25 \mathrm{mmHg})$;

b: denotes statistical significance between Non-PAH and PAH ( $>25 \mathrm{mmHg}$ );

c: denotes statistical significance between PAH $(20-25 \mathrm{mmHg})$ and PAH $(>25 \mathrm{mmHg}$ ) 
Table 2 Association between EPCs and PAH by multivariate logistic regression models

\begin{tabular}{|c|c|c|c|c|c|c|}
\hline \multirow{2}{*}{$\begin{array}{l}\text { EPCs, } \\
\mu \mathrm{L} \\
\text { Levels }\end{array}$} & \multicolumn{3}{|c|}{ PAH (20-25 mmHg) Odds Ratio(95\%Cl) } & \multicolumn{3}{|c|}{ PAH(> 25 mmHg) Odds Ratio(95\%Cl) } \\
\hline & Unadjusted & Age and gender adjusted & Multivariate adjusted+ & Unadjusted & Age and gender adjusted & Multivariate adjusted + \\
\hline$\leq 1.00$ & 1 & 1 & 1 & 1 & 1 & 1 \\
\hline$>1.00$ & $0.99(0.41-2.38)$ & $0.95(0.39-2.31)$ & $0.95(0.39-2.33)$ & $0.42(0.19-0.95)$ * & $0.38(0.17-0.87) *$ & $0.37(0.16-0.87) *$ \\
\hline
\end{tabular}

${ }^{*}$ Compared with EPCs $\leq 1.00: P<0.05 ;+$ Adjusted: gender, age, and BMI

expressed in early EPCs but absent in mature endothelial cells, which is the surface marker of EPCs [30, 31]. KDR is an important marker of endothelial tissue [32, 33]. However, CD34 expressed in endothelial cells at any stage cannot be used as a specific marker of EPCs [12, $27,33]$. Therefore, flow cytometry was used in this study to define CD133+/KDR+ cells as EPCs. It has been proved that $\mathrm{CD} 133+/ \mathrm{KDR}+$ cells can differentiate into endothelial cells in vitro and in vivo, contributing to the re-endothelialization of the left heart, and promoting endothelial regeneration at the site of ischemia and vascular injury [12]. Since there is no unified definition and classification of EPCs surface markers at present, some researchers have used combinations of other surface markers to identify different EPCs subgroups [19, 20,34].

In the present study, both unadjusted and adjusted mPAP decline steadily with the increase in the level of EPCs. For patients with EPCs $>1.00 / \mu \mathrm{L}$, the risk of high $\mathrm{PAH}(>25 \mathrm{mmHg}$ ) was significantly lower than that for patients with $\mathrm{EPCs}<1.00 / \mu \mathrm{L}(P<0.05)$, regardless of adjusting gender, age, and BMI or not. However, a significant difference in risk of PAH between EPCs and the middle PAH $(20-25 \mathrm{mmHg})$ was not found $(P>0.05)$. $\mathrm{PAH}$ severity is negatively correlated with the number of EPCs, suggesting that the reduction of EPCs increases the risk of PAH among patients with CHD. At present, there are no studies on the relationship between EPCs and $\mathrm{PAH}$ in children with CHD. In the study by Zhu et al., $[1,14]$ the number of EPCs is reduced in idiopathic $\mathrm{PAH}$, which is consistent with our study. Liu et al. [15] also found that EPCs in PAH combined with the chronic obstructive pulmonary disease was decreasing. However, Schiavon et al. [13] concluded that elevated EPCs in patients with end-stage PAH may be associated with a long course of illness, leading to a compensatory proliferation of EPCs. Other surface markers have been used to identify other EPCs subsets. Some scholars [16, 35]. argue that reduced EPCs levels may lead to endothelial dysfunction in CHD patients, triggering PAH. Due to the continuous damage of pulmonary artery endothelial cells caused by PAH, EPCs are mobilized to repair them, and then EPCs are gradually exhausted. The higher the MPAP is, the more EPCs are consumed, while EPCs cells are reduced, thereby affecting the repair of pulmonary artery endothelial cells and causing a vicious cycle. Sen et al. [12] believe EPCs to be an important marker of cardiovascular diseases.

Through this study, we believe that in patients with CHD, endothelial cells may be damaged or functioned due to the increase of blood flow or accelerated flow rate in the pulmonary artery and EPCs are largely used to repair endothelial cells, leading to a decrease in the number. EPCs can be assumed to be a protective factor of PAH and associated with PAP. According to the present study, no difference in the middle PAH group is probably because that the condition of these patients is relatively mild, and the peripheral blood EPCs are enough to repair the endothelial injury; so the EPCs are not excessively consumed. Recent studies have found that EPCs play an important role in maintaining vascular homeostasis, reversing pulmonary vascular remodeling and promoting angiogenesis; their function is to participate in the differentiation of vascular smooth muscle cells and potential cardiomyocytes by releasing cytokines, growth factors, and chemokines [34, 36, 37]. In addition, various cytokines and VEGF may inhibit the mobilization of bone marrow EPCs and indirectly reduce peripheral EPCs [38, 39]. By releasing angiogenic factors, anti-apoptotic factors and anti-inflammatory factors, some cells can be differentiated or have paracrine to play the therapeutic role of progenitor cells $[10,16]$. Thus, EPCs have been used in treating PAH in animal studies and achieved good results [40-42]. Lavoie et al. [43] applied EPCs in the experimental treatment of idiopathic PAH patients and found that the PAP decreased to varying degrees, but could not be completely reduced to a normal level. Hence, the treatment should still be combined with pulmonary artery antihypertensive drugs. It has provided a good prospect for the radical treatment of PAH.

According to our study, EPCs may be a protective factor of PAH in children with CHD. Therefore, EPCs may be an effective treatment for patients with CHD complicated with PAH, if the PAP cannot be reduced to a normal level after surgery,.

Strengths and limitation: There are few studies about the relationship between EPCs and PAH in children with CHD. A rigorous experimental design was carried out strictly. Three types of CHD (PDA, ASD, and VSD) are included in the study, which may affect the final results. We will continue to conduct research on a specific CHD to obtain more scientific results. Due to the low incidence of $\mathrm{PAH}$ in children with $\mathrm{CHD}$, the sample size of 
the experiment was small which may affect the results. In the further experiment, we will collect more samples to confirm our conclusion.

\section{Conclusion}

The current study revealed the relationship between EPCs and PAH in children with CHD. The findings suggest that a reduction of the number of EPCs in children with CHD may be associated with an increase in mPAP. There was a significant correlation between EPCs and high PAH in CHD patients and EPCs may become an effective treatment for $\mathrm{PAH}$ in $\mathrm{CHD}$ patients.

\author{
Abbreviations \\ CHD: Congenital Heart Disease; EPCs: Endothelial Progenitor Cells; \\ mPAP: Mean Pulmonary Arterial Pressure; PAH: Pulmonary Arterial \\ Hypertension
}

\section{Acknowledgements}

Not applicable.

\section{Authors' contributions}

All authors contributed to the design or implementation of the study and approved the final manuscript as submitted. HXS had primary responsibility for patient screening, enrollment, outcome assessment, and drafted the manuscript. GJL performed the data analysis and drafted the manuscript. ZHD reviewed and revised the paper. ZB contributed to patient screening and enrollment. ZHJ contributed to the outcome assessment. GL summarized clinical data. SLP was responsible for study conception and design.

\section{Funding}

The work was financially supported by the National Natural Science Foundation of China (No. 81770316) and Shandong Taishan Scholarship (2017). The funding bodies only provides financial assistance, but does not provide assistance in the design of the study and collection, analysis, interpretation of data and in writing the manuscript.

\section{Availability of data and materials}

The datasets used and/or analysed during the current study are available from the corresponding author on reasonable request.

\section{Ethics approval and consent to participate}

The study was conducted in accordance with the Declaration of Helsinki and approved by the local ethics committee of Qingdao Women and Children's Hospital (No. QFELL-KY-2019-034). All participants' guardians signed the informed consent.

\section{Consent for publication}

Not applicable.

\section{Competing interests}

The authors declare that they have no competing interests.

\section{Author details}

${ }^{1}$ Medical College, Qingdao University, Qingdao 266071, Shandong, China. ${ }^{2}$ Heart Center, Qingdao Women and Children's Hospital, Qingdao 266034, Shandong, China.

Received: 30 October 2019 Accepted: 11 December 2019

Published online: 17 December 2019

\section{References}

1. Hoeper MM, Humbert M, Souza R, Idrees M, Kawut SM, Sliwa-Hahnle K, et al. A global view of pulmonary hypertension. Lancet Respir Med. 2016;4(4): 306-22. https://doi.org/10.1016/S2213-2600(15)00543-3.

2. Lowe BS, Therrien J, Ionescu-Ittu R, Pilote L, Martucci G, Marelli AJ. Diagnosis of pulmonary hypertension in the congenital heart disease adult population impact on outcomes. J Am Coll Cardiol. 2011;58(5):538-46. https://doi.org/ 10.1016/j.jacc.2011.03.033.

3. Ntiloudi D, Zanos S, Gatzoulis MA, Karvounis H, Giannakoulas G. How to evaluate patients with congenital heart disease-related pulmonary arterial hypertension. Expert Rev Cardiovasc Ther. 2019;17(1):11-8. https://doi.org/ 10.1080/14779072.2019.1550716.

4. Giannakoulas G, Vasiliadis K, Frogoudaki A, Ntellos C, Tzifa A, Brili S, et al. Adult congenital heart disease in Greece: preliminary data from the CHALLENGE registry. Int J Cardiol. 2017;245:109-13. https://doi.org/10.1016/j.ijcard.2017.07.024.

5. Fathallah M, Krasuski RA. A multifaceted approach to pulmonary hypertension in adults with congenital heart disease. Prog Cardiovasc Dis. 2018;61(3-4):320-7. https://doi.org/10.1016/j.pcad.2018.07.017.

6. Roth TS, Aboulhosn JA. Pulmonary hypertension and congenital heart disease. Cardiol Clin. 2016;34(3):391-400. https://doi.org/10.1016/j.ccl.2016.04.002.

7. Verheugt $\mathrm{CL}$, Uiterwaal CS, van der Velde ET, Meijboom FJ, Pieper PG, van Dijk AP, et al. Mortality in adult congenital heart disease. Eur Heart J. 2010; 31(10):1220-9. https://doi.org/10.1093/eurheartj/ehq032.

8. Rich S, Dantzker DR, Ayres SM, Bergofsky EH, Brundage BH, Detre KM, et al. Primary pulmonary hypertension. A national prospective study. Ann Intern Med. 1987;107(2):216-23. https://doi.org/10.7326/0003-4819-107-2-216.

9. Asahara T, Murohara T, Sullivan A, Silver M, van der Zee $R$, Li T, et al. Isolation of putative progenitor endothelial cells for angiogenesis. Science. 1997:275(5302):964-7. https://doi.org/10.1126/science.275.5302.964.

10. Anversa P, Perrella MA, Kourembanas S, Choi AM, Loscalzo J. Regenerative pulmonary medicine: potential and promise, pitfalls and challenges. Eur J Clin Investig. 2012;42(8):900-13. https://doi.org/10.1111/j.1365-2362.2012.02667.x.

11. Weiss DJ. Concise review: current status of stem cells and regenerative medicine in lung biology and diseases. Stem Cells. 2014;32(1):16-25. https:// doi.org/10.1002/stem.1506.

12. Sen S, McDonald SP, Coates PT, Bonder CS. Endothelial progenitor cells: novel biomarker and promising cell therapy for cardiovascular disease. Clin Sci (Lond). 2011;120(7):263-83. https://doi.org/10.1042/CS20100429.

13. Schiavon M, Fadini GP, Lunardi F, Agostini C, Boscaro E, Calabrese F, et al. Increased tissue endothelial progenitor cells in end-stage lung diseases with pulmonary hypertension. J Heart Lung Transplant. 2012;31(9):1025-30. https://doi.org/10.1016/j.healun.2012.06.005.

14. Junhui Z, Xingxiang W, Guosheng F, Yunpeng S, Furong Z, Junzhu C. Reduced number and activity of circulating endothelial progenitor cells in patients with idiopathic pulmonary arterial hypertension. Respir Med. 2008; 102(7):1073-9. https://doi.org/10.1016/j.rmed.2007.12.030.

15. Liu P, Zhang H, Liu J, Sheng C, Zhang L, Zeng Y. Changes of number and function of late endothelial progenitor cells in peripheral blood of COPD patients combined with pulmonary hypertension. Thorac Cardiovasc Surg. 2016:64(4):323-9. https://doi.org/10.1055/s-0034-1389261.

16. Toshner M, Morrell NW. Endothelial progenitor cells in pulmonary hypertension - dawn of cell-based therapy? Int J Clin Pract Suppl. 2010; 64(165):7-12. https://doi.org/10.1111/j.1742-1241.2009.02232.x.

17. Baumgartner H, Bonhoeffer P, De Groot NM, de Haan F, Deanfield JE, Galie $\mathrm{N}$, et al. ESC guidelines for the management of grown-up congenital heart disease (new version 2010). Eur Heart J. 2010;31(23):2915-57. https://doi.org/ 10.1093/eurheartj/ehq249.

18. Simonneau G, Montani D, Celermajer DS, Denton CP, Gatzoulis MA, Krowka $M$, et al. Haemodynamic definitions and updated clinical classification of pulmonary hypertension. Eur Respir J. 2019;53(1). https://doi.org/10.1183/ 13993003.01913-2018.

19. Duda DG, Cohen KS, Scadden DT, Jain RK. A protocol for phenotypic detection and enumeration of circulating endothelial cells and circulating progenitor cells in human blood. Nat Protoc. 2007;2(4):805-10. https://doi. org/10.1038/nprot.2007.111.

20. Chopra H, Hung MK, Kwong DL, Zhang CF, Pow EHN. Insights into endothelial progenitor cells: origin, classification, potentials, and prospects. Stem Cells Int. 2018:2018:1-24. https://doi.org/10.1155/2018/9847015.

21. Benza RL, Miller DP, Barst RJ, Badesch DB, Frost AE, McGoon MD. An evaluation of long-term survival from time of diagnosis in pulmonary arterial hypertension from the REVEAL registry. Chest. 2012;142(2):448-56. https://doi.org/10.1378/chest.11-1460.

22. YYL XCL, ZD YDY. correlation between the embolism area and pulmonary arterial systolic pressure as an indicator of pulmonary arterial hypertension in patients with acute pulmonary thromboembolism. Eur Rev Med Pharmacol Sci. 2014;18(17):2551-5.

23. Lammers AE, Apitz C, Zartner P, Hager A, Dubowy KO, Hansmann G. Diagnostics, monitoring and outpatient care in children with suspected 
pulmonary hypertension/paediatric pulmonary hypertensive vascular disease. Expert consensus statement on the diagnosis and treatment of paediatric pulmonary hypertension. The European Paediatric Pulmonary Vascular Disease Network, endorsed by ISHLT and DGPK. Heart. 2016;102 Suppl 2:ii1-13; doi: https://doi.org/10.1136/heartjnl-2015-307792.

24. Kovacs G, Berghold A, Scheidl S, Olschewski H. Pulmonary arterial pressure during rest and exercise in healthy subjects: a systematic review. Eur Respir J. 2009;34(4):888-94. https://doi.org/10.1183/09031936.00145608.

25. Shi Q, Rafii S, Wu MH, Wijelath ES, Yu C, Ishida A, et al. Evidence for circulating bone marrow-derived endothelial cells. Blood. 1998;92(2):362-7. https://doi.org/10.1006/bcmd.1998.0195.

26. Tura O, Skinner EM, Barclay GR, Samuel K, Gallagher RC, Brittan M, et al. Late outgrowth endothelial cells resemble mature endothelial cells and are not derived from bone marrow. Stem Cells. 2013;31(2):338-48. https://doi.org/ 10.1002/stem.1280.

27. Timmermans F, Van Hauwermeiren F, De Smedt M, Raedt R, Plasschaert F, De Buyzere $M L$, et al. Endothelial outgrowth cells are not derived from CD133+ cells or CD45+ hematopoietic precursors. Arterioscler Thromb Vasc Biol. 2007;27(7):1572-9. https://doi.org/10.1161/ATVBAHA.107.144972.

28. Peichev M, Naiyer AJ, Pereira D, Zhu Z, Lane WJ, Williams M, et al. Expression of VEGFR-2 and AC133 by circulating human CD34(+) cells identifies a population of functional endothelial precursors. Blood. 2000; 95(3):952-8. https://doi.org/10.1007/s002770050019.

29. Medina RJ, O'Neill CL, Sweeney M, Guduric-Fuchs J, Gardiner TA, Simpson DA, et al. Molecular analysis of endothelial progenitor cell (EPC) subtypes reveals two distinct cell populations with different identities. BMC Med Genet. 2010;3:18. https://doi.org/10.1186/1755-8794-3-18.

30. Yin AH, Miraglia S, Zanjani ED, Almeida-Porada G, Ogawa M, Leary AG, et al. AC133, a novel marker for human hematopoietic stem and progenitor cells. Blood. 1997;90(12):5002-12. https://doi.org/10.1006/ bemd.1997.0163.

31. Gehling UM, Ergun S, Schumacher U, Wagener C, Pantel K, Otte M, et al. In vitro differentiation of endothelial cells from AC133-positive progenitor cells. Blood. 2000;95(10):3106-12. https://doi.org/10.1016/ S0955-3886(00)00041-2.

32. Cheng SM, Chang SJ, Tsai TN, Wu CH, Lin WS, Lin WY, et al. Differential expression of distinct surface markers in early endothelial progenitor cells and monocyte-derived macrophages. Gene Expr. 2013;16(1):15-24. https:// doi.org/10.3727/105221613×13776146743307.

33. Cheng CC, Chang SJ, Chueh YN, Huang TS, Huang PH, Cheng SM, et al. Distinct angiogenesis roles and surface markers of early and late endothelial progenitor cells revealed by functional group analyses. BMC Genomics. 2013;14(1):182. https://doi.org/10.1186/1471-2164-14-182.

34. Minami $Y$, Nakajima T, Ikutomi M, Morita T, Komuro I, Sata M, et al. Angiogenic potential of early and late outgrowth endothelial progenitor cells is dependent on the time of emergence. Int J Cardiol. 2015;186:305-14. https://doi.org/10.1016/j.ijcard.2015.03.166.

35. Heissig B, Hattori K, Dias S, Friedrich M, Ferris B, Hackett NR, et al. Recruitment of stem and progenitor cells from the bone marrow niche requires MMP-9 mediated release of kit-ligand. Cell. 2002;109(5):625-37. https://doi.org/10.1016/s0092-8674(02)00754-7.

36. Mudyanadzo TA. Endothelial progenitor cells and cardiovascular correlates. Cureus. 2018;10(9):e3342. https://doi.org/10.7759/cureus.3342.

37. Richards WO, Prutzman KB, O'Hea MF, Audia JP, Alvarez DF. Bariatric surgery improves the circulating numbers and biological activity of late outgrowth endothelial progenitor cells. Surg Obes Relat Dis. 2014;10(5):906-13. https:// doi.org/10.1016/j.soard.2014.04.025.

38. Fadini GP, Schiavon M, Cantini M, Avogaro A, Agostini C. Circulating CD34+ cells, pulmonary hypertension, and myelofibrosis. Blood. 2006;108(5):1776-7. https://doi.org/10.1182/blood-2006-02-005892.

39. Nowak K, Rafat N, Belle S, Weiss C, Hanusch C, Hohenberger P, et al. Circulating endothelial progenitor cells are increased in human lung cancer and correlate with stage of disease. Eur J Cardiothorac Surg. 2010;37(4):75863. https://doi.org/10.1016/j.ejcts.2009.10.002.

40. Ahmed LA, Rizk SM, El-Maraghy SA. Pinocembrin ex vivo preconditioning improves the therapeutic efficacy of endothelial progenitor cells in monocrotaline-induced pulmonary hypertension in rats. Biochem Pharmacol. 2017;138:193-204. https://doi.org/10.1016/j.bcp.2017.04.024.

41. Sun CK, Lin YC, Yuen CM, Chua S, Chang LT, Sheu JJ, et al. Enhanced protection against pulmonary hypertension with sildenafil and endothelial progenitor cell in rats. Int J Cardiol. 2012;162(1):45-58. https://doi.org/10. 1016/j.jijcard.2011.05.002.

42. Aliotta JM, Pereira M, Wen S, Dooner MS, Del Tatto M, Papa E, et al. Bone marrow endothelial progenitor cells are the cellular mediators of pulmonary hypertension in the murine Monocrotaline injury model. Stem Cells Transl Med. 2017:6(7):1595-606. https://doi.org/10.1002/sctm.16-0386.

43. Lavoie JR, Stewart DJ. Genetically modified endothelial progenitor cells in the therapy of cardiovascular disease and pulmonary hypertension. Curr Vasc Pharmacol. 2012;10(3):289-99. https://doi.org/10.2174/ 157016112799959413

\section{Publisher's Note}

Springer Nature remains neutral with regard to jurisdictional claims in published maps and institutional affiliations.
Ready to submit your research? Choose BMC and benefit from:

- fast, convenient online submission

- thorough peer review by experienced researchers in your field

- rapid publication on acceptance

- support for research data, including large and complex data types

- gold Open Access which fosters wider collaboration and increased citations

- maximum visibility for your research: over $100 \mathrm{M}$ website views per year

At BMC, research is always in progress.

Learn more biomedcentral.com/submissions 